\title{
Scientific Notes
}

\section{Production of 'Valência' sweet orange on 41 rootstocks in the north of the state of São Paulo, Brazil}

\author{
André Luiz Fadel (1), Francisco de Assis Alves Mourão Filho(1), \\ Eduardo Sanches Stuchi(2) and Yuri Caires Ramos ${ }^{(1)}$
}

\begin{abstract}
(1)Universidade de São Paulo, Escola Superior de Agricultura Luiz de Queiroz, Avenida Pádua Dias, no 11, CEP 13418-900 Piracicaba, SP, Brazil. E-mail: aluizfadel@gmail.com, francisco.mourao@usp.br, cairesramos@usp.br (2)Embrapa Mandioca e Fruticultura, Rua Embrapa, s/no, Caixa Postal 007, CEP 44380-000 Cruz das Almas, BA, Brazil. E-mail: eduardo.stuchi@embrapa.br
\end{abstract}

\begin{abstract}
The objective of this work was to select alternative rootstocks to 'Rangpur' lime for 'Valência' sweet orange scions in the northern region of the state of São Paulo, Brazil, based on initial fruit yield. Forty-one rootstocks were evaluated in an experiment carried out in March 2007, in the municipality of Colômbia, in the state of São Paulo. The accumulated fruit yield of 'Valência' sweet orange was assessed in the 2009, 2010, and 2011 crop seasons. The rootstocks 'Sunki' mandarin x Poncirus trifoliata 'English', 'Malvasio SRA 115' mandarin, 'C-13' “S” citrange, 'Sunki' mandarin x P. trifoliata 'Benecke', 'Valência Rhode Red' sweet orange + 'Volkamer' lemon, 'C-54-4-4 SRA 337' mandarin, 'Cleopatra' mandarin x P. trifoliata 'Rubidoux', and 'À Peau Lisse SRA 267' have potential to replace 'Rangpur' lime in the northern region of the state of São Paulo, Brazil.
\end{abstract}

Index terms: Citrus, Citrus limonia Osbeck, citrus sudden death, drought tolerance, 'Rangpur' lime.

\section{Produção de laranjeira 'Valência' sobre 41 porta-enxertos no Norte do Estado de São Paulo}

Resumo - O objetivo deste trabalho foi selecionar porta-enxertos alternativos ao limoeiro 'Cravo' para laranjeira 'Valência', para a região Norte do Estado de São Paulo, com base na produção inicial de frutos. Foram avaliados 41 porta-enxertos em experimento realizado em março de 2007, no Município de Colômbia, SP. Avaliou-se a produção acumulada de frutos de laranjeira 'Valência' nas safras de 2009, 2010 e 2011. Os porta-enxertos tangerineira 'Sunki' x P. trifoliata 'English', tangerineira 'Malvasio SRA 115', citrange 'C-13' "S", tangerineira 'Sunki' x P. trifoliata 'Benecke', laranjeira 'Rhode Red Valência' + limoeiro 'Volkameriano', tangerineira 'C-54-4-4 SRA 337', tangerineira 'Cleópatra' x P. trifoliata 'Rubidoux' e tangerineira 'À Peau Lisse SRA 267' apresentam potencial para substituir o limoeiro 'Cravo' na região Norte do Estado de São Paulo.

Termos para indexação: Citrus, Citrus limonia Osbeck, morte súbita dos citros, tolerância à seca, limoeiro 'Cravo'.

'Rangpur' lime (Citrus limonia Osbeck) is a commonly used citrus rootstock in Brazil due to its adequate vigor, as well as to its capacity to induce early bearing (precocity), high yields, and drought tolerance in the scions budded on it (Castle, 2010; Pedroso et al., 2014). However, its use has limitations in the northern region of the state of São Paulo, because of its susceptibility to citrus sudden death (CSD), a disease of high incidence there (Bové \& Ayres, 2007). For this reason and due to the low rootstock diversity in the country, this region requires alternative rootstocks, which must also be tolerant to drought in order to assure adequate yields in nonirrigated orchards, considering the relatively low average rainfall and high temperatures recorded during some periods. In order to do this, it is necessary to establish new groves with highly-efficient scion/rootstock combinations.

The objective of this work was to select alternative rootstocks to 'Rangpur' lime for 'Valência' sweet orange scions in the northern region of the state of São Paulo, Brazil, based on initial fruit yield. Creative Commons Attribution 4.0 International License 
The experiment was established at a site belonging to the company Citrosuco, located in the municipality of Colômbia, in the northern region of the state of São Paulo, Brazil $\left(20^{\circ} 19^{\prime} 39^{\prime \prime} \mathrm{S}, 48^{\circ} 41^{\prime} 16^{\prime \prime} \mathrm{W}\right)$. The soil is classified as a Latossolo Vermelho-Escuro (Santos et al., 2013), i.e., a Rhodic Hapludox. According to Köppen's classification, the climate is Aw, tropical, rainy, with a dry winter. The average minimum temperature was $17^{\circ} \mathrm{C}$, the average maximum temperature was $30.7^{\circ} \mathrm{C}$, and annual rainfall was $1,430 \mathrm{~mm}$ (Cepagri, 2014).

The different scion/rootstock combinations were planted in March 2007, in 6.0-m rows, with $2.5 \mathrm{~m}$ between trees, without irrigation. The experimental design was a randomized complete block, with 41 treatments, with three replicates of five plants each. 'Valência' sweet orange [Citrus sinensis (L.) Osbeck] was budded on 41 different rootstocks: 'CNPMF 003 Rangpur' lime (C. limonia); 'Santa Cruz Rangpur' lime (C. limonia); 'Allspice SRA 327' tangelo (Citrus reticulata Blanco x Citrus paradisi Macfad.); 'Lebon SRA 425' mandarin (C. reticulata); 'Ponkan Yoshida SRA 585' mandarin (C. reticulata); 'Antillaise SRA 497' mandarin (C. reticulata); 'Minneola' tangelo $(C$. reticulata $\times$ C. paradisi) x Poncirus trifoliata (L.) Raf.; 'C-32' citrange (Citrus sinensis x P.trifoliata); 'C-54-4-4 SRA 337' mandarin (C. reticulata); 'Malvasio SRA 115' mandarin $(C$. reticulata); 'Fortune SRA 31' mandarin (C. reticulata); 'Carvalhais' mandarin (C. reticulata); 'Fuzhu SRA 599' mandarin (Citrus erythrosa hort. ex Tanaka); 'Cleopatra' mandarin (Citrus reshni hort. ex Tanaka) x $P$. trifoliata 'Rubidoux'; 'Wallent SRA 438' mandarin (C. reticulata); 'Sunki' mandarin (C. sunki hort. ex Tanaka) x P. trifoliata 'English'; 'Beauty of Glen Retreat SRA 261' mandarin (Citrus tangerina Tanaka); 'East India SRA 414' mandarin (C. reticulata); 'Burgess SRA 412' mandarin (C. reticulata); 'À Peau Lisse SRA 267' mandarin (Citrus deliciosa Ten.); 'Ananas SRA 410' mandarin (C. reticulata); 'Clanor SRA 391' sweet orange (C. sinensis); 'Sunki' mandarin (C. sunki) x P. trifoliata 'Benecke'; 'Gem SRA 393' sweet orange (C. sinensis); 'OMO 24' tangor (Citrus clementina hort. ex Tan. x C. sinensis); 'Natal Tightskin SRA 481' mandarin (C. deliciosa); 'C-13' "S" citrange (C. sinensis $\mathrm{x}$ P. trifoliata); 'Redskin SRA 428' mandarin (C. deliciosa); 'Temple Sue Linda SRA 467' mandarin (Citrus temple hort. ex Yu.Tanaka); 'Late Emperor SRA 423' mandarin (C. deliciosa); 'Mapo' tangelo (C. reticulata x C. paradisi); 'Calamondin' x 'King' mandarin (Citrus madurensis Lour. x Citrus nobilis Lour.); 'OMO 16' tangor (C. clementina x C. sinensis); 'Thornton Vero SRA 460' tangelo (C. reticulata $\mathrm{x}$ $C$. paradisi); 'Valência Rhode Red' sweet orange (C. sinensis) + 'Volkamer' lemon (C. limonia); 'Caipira' sweet orange $(C$. sinensis $)+$ 'Volkamer' lemon (C. limonia); 'Caipira' sweet orange $(C$. sinensis $)+$ 'Rough' lemon (Citrus jambhiri Lush.); 'Caipira' sweet orange (C. sinensis) + 'Cleopatra' mandarin (C. reshni); 'Cleopatra' mandarin $(C$. reshni $)+$ 'Volkamer' lemon (C. limonia); 'Rangpur' lime (C. limonia) + 'Sunki' mandarin (C. sunki); and 'Caipira' sweet orange (C. sinensis) + 'Rangpur' lime (C. limonia).

The materials used as rootstocks were from the germplasm banks of the citrus experimental station located in Bebedouro, in the state of São Paulo, and of Embrapa Mandioca e Fruticultura, in Cruz das Almas, in the state of Bahia, Brazil. Seven somatic hybrids were developed at Escola Superior de Agricultura Luiz de Queiroz and at Centro de Energia Nuclear na Agricultura, both located at Universidade de São Paulo. Total fruit yield was first obtained in the 2009 harvest, i.e., two years after the experiment was established, and then in 2010 and 2011. Data were presented as total accumulated yield, in kilogram of fruits per plant (Figure 1).

Fruit harvest was carried out in October and November of each year, taking into account the adequate maturing time of 'Valência' sweet orange and the harvest schedule followed by the company for the northern region of the state of São Paulo. The total amount of fruits in each replicate was gathered in harvest bags that held up to 20 boxes $(40.8 \mathrm{~kg})$ of fruit. The bags were lifted by a hydraulic winch, and total fruit mass was determined using the PR30 digital dynamometer (Líder Balanças, Araçatuba, SP, Brazil).

Data on the accumulated yield of the different scion/ rootstock combinations were analyzed through the test for homogeneity of variance (Box-Cox test) and the cluster analysis, where the replicates (blocks) of the experimental design were considered the different variables in the multivariate analysis (replicates subdivided in space). For group separation, the cutoff distance was defined based on accumulated yield values above $50 \mathrm{~kg}$ per plant. Finally, the average accumulated yield values of each group were compared by the Tukey-Kramer test, at $5 \%$ probability.

Pesq. agropec. bras., Brasília, v.53, n.6, p.774-778, June 2018 DOI: 10.1590/S0100-204X2018000600015 


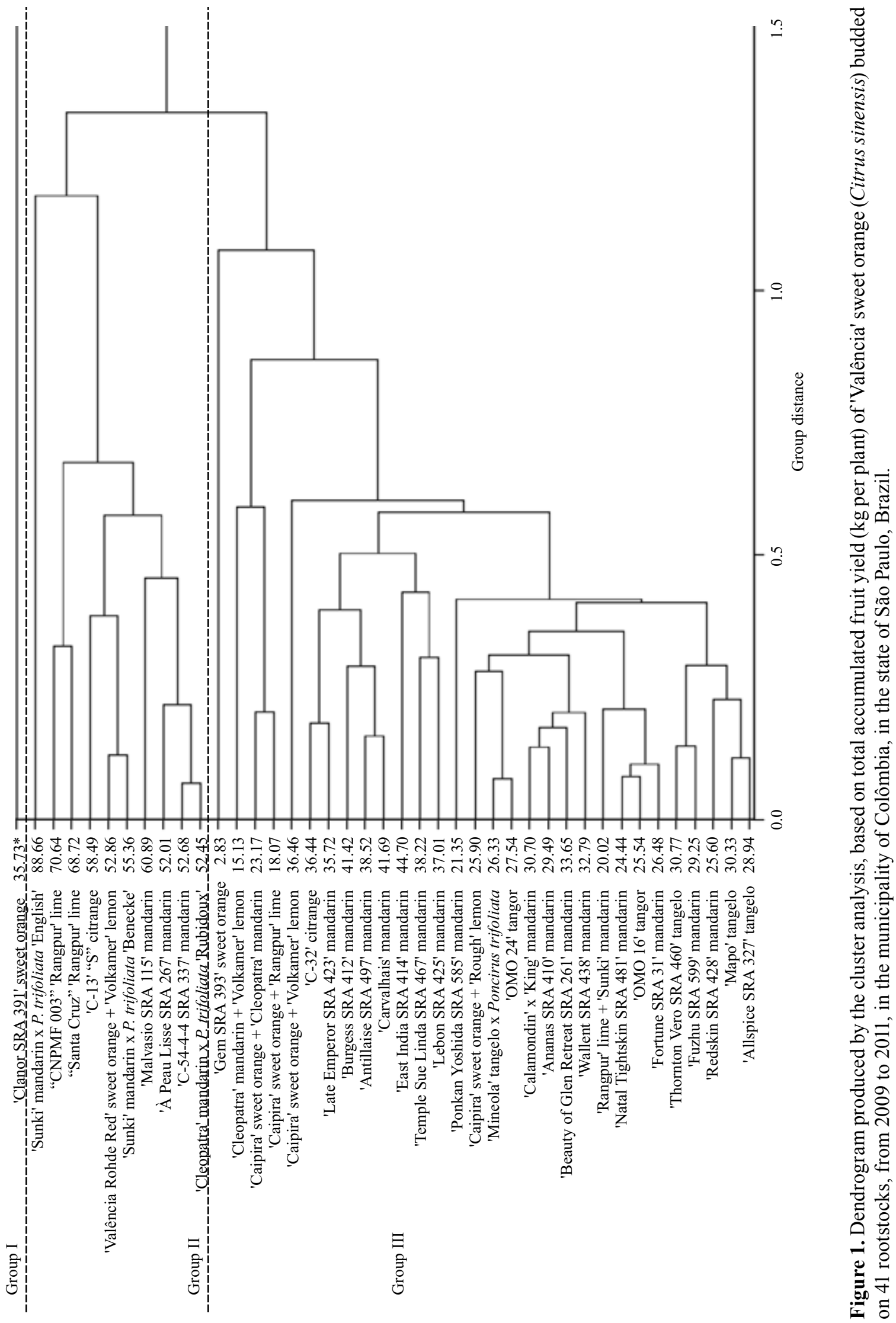


'Valência' sweet orange plants budded on the 'Sunki' mandarin x P. trifoliata 'English' hybrid, and on the 'CNPMF 03' and 'Santa Cruz Rangpur' lime selections showed the highest total accumulated yield for the three harvests (Figure 1). 'Valência' sweet orange grafted on 'Sunki' mandarin x P. trifoliata 'English' also had a better performance for average yield, which was reported previously in Colombia (ChaparroZambrano et al., 2015). In another research, 'Valência' sweet orange had higher yields when budded on 'Changsha' mandarin x $P$. trifoliata 'English Large' (HRS 852), compared with 12 rootstocks, during 9 harvests, in Pirassununga, in the state of São Paulo, Brazil (Pompeu Jr. et al., 2002).

'Valência' sweet orange plants budded on the 'Sunki' mandarin x P. trifoliata 'Benecke' hybrid were among those with the highest yields (Figure 1). In other studies, this hybrid also showed a very good performance when used as a rootstock for 'Valência' sweet orange in Florida (Wutscher \& Bowman, 1999) and again in Brazil (Pompeu Jr. et al., 2002).

The adequate performance of other $P$. trifoliata hybrid rootstocks for sweet orange has also been observed by Bowman et al. (2016). These authors found that the combination 'Valência' sweet orange and $C$. grandis Osbeck 'African' $\times P$. trifoliata 'Flying Dragon' (US-1516) showed good yield and the lowest number of eradicated plants due to huanglongbing incidence.

Among the highest-yielding scion/rootstock combinations, three included mandarin $\mathrm{x} P$. trifoliata hybrids (Figure 1). This finding emphasizes the good performance of hybrids between mandarins and P. trifoliata as rootstocks for sweet oranges, as reported before (Pompeu Jr. \& Blumer, 2014).

According to the obtained results, plants of 'Valência' sweet orange budded on 'Sunki' mandarin $\mathrm{x}$ P. trifoliata 'English', 'Malvasio SRA 115' mandarin, 'C-13' “S”citrange, 'Sunki' mandarin x $P$. trifoliata 'Benecke', 'Valência Rhode Red' sweet orange + 'Volkamer' lemon, 'C-54-4-4 SRA 337' mandarin, 'Cleopatra' mandarin x P. trifoliata 'Rubidoux', and 'À Peau Lisse SRA 267' mandarin, together with the two 'Rangpur' lime selections, were classified in the group of the most high-yielding combinations, considering accumulated yield in the first harvest years (Figure 1); this group differed significantly from the other ones (Table 1). Although a more detailed investigation
Table 1. Average accumulated fruit yield of the three groups of 'Valência' sweet orange (Citrus sinensis) budded on 41 rootstocks, from 2009 to 2011, in the municipality of Colômbia, in the state of São Paulo, Brazil.

\begin{tabular}{lc}
\hline Group & Average accumulated fruit yield (kg per plant) \\
\hline II & $61.27 \mathrm{a}$ \\
I & $35.73 \mathrm{~b}$ \\
III & $29.28 \mathrm{~b}$ \\
\hline
\end{tabular}

${ }^{(1)}$ Means followed by equal letters do not differ by the Tukey-Kramer test, at $5 \%$ probability.

regarding fruit quality, drought tolerance, and CSD tolerance is necessary, these results confirm the potential of these eight scion/rootstock combinations as alternative rootstocks to 'Rangpur' lime for 'Valência' sweet orange scions, in the north of the state of São Paulo, Brazil.

\section{Acknowledgments}

To Dr. Walter Soares Filho, Helton Carlos de Leão, and André Luiz Vanucci da Silva, for their contribution in the development of this research; to Professor Dr. Hilton Thadeu Zarate Couto, for his support on statistical analyses; to Citrosuco, for logistics and financial support; and to Conselho Nacional de Desenvolvimento Científico e Tecnológico (CNPq), for financial support.

\section{References}

BOVÉ, J.M.; AYRES, A.J. Etiology of three recent diseases of citrus in São Paulo State: sudden death, variegated chlorosis and huanglongbing. IUBMB Life, v.59, p.346-354, 2007. DOI: 10.1080/15216540701299326.

BOWMAN, K.D.; MCCOLLUM, G.; ALBRECHT, U. Performance of 'Valencia' orange (Citrus sinensis [L.] Osbeck) on 17 rootstocks in a trial severely affected by huanglongbing. Scientia Horticulturae, v.201, p.355-361, 2016. DOI: 10.1016/j. scienta.2016.01.019.

CASTLE, W.S. A career perspective on citrus rootstocks, their development, and commercialization. HortScience, v.45, p.11-15, 2010.

CEPAGRI. Centro de Pesquisas Meteorológicas e Climáticas Aplicadas à Agricultura. Clima dos municípios paulistas: Colômbia. Available at: <http://www.cpa.unicamp.br/outrasinformacoes/clima_muni_137.html>. Accessed on: Nov. 172014.

CHAPARRO-ZAMBRANO, H.N.; VELÁZQUEZ, H.A.; ORDUZ-RODRÍGUEZ, J.O. Performance of 'Valencia' sweet 
orange grafted in different rootstocks, Colombia Tropical Lowland. 2001-2013. Agronomía Colombiana, v.33, p.43-48, 2015. DOI: 10.15446/agron.colomb.v33n1.49497.

PEDROSO, F.K.J.V.; PRUDENTE, D.A.; BUENO, A.C.R.; MACHADO, E.C.; RIBEIRO, R.V. Drought tolerance in citrus trees is enhanced by rootstock-dependent changes in root growth and carbohydrate availability. Environmental and Experimental Botany, v.101, p.26-35, 2014. DOI: 10.1016/j. envexpbot.2013.12.024.

POMPEU JR., J.; BLUMER, S. Híbridos de trifoliata como portaenxertos para laranjeira Pêra. Pesquisa Agropecuária Tropical, v.44, p.9-14, 2014. DOI: 10.1590/S1983-40632014000100007.
POMPEU JR., J.; LARANJEIRA, F.F.; BLUMER, S. Laranjeiras 'Valência' enxertadas em híbridos de trifoliata. Scientia Agricola, v.59, p.93-97, 2002. DOI: 10.1590/S010390162002000100014.

SANTOS, H.G. dos; JACOMINE, P.K.T.; ANJOS, L.H.C. dos; OLIVEIRA, V.A. de; LUMBRERAS, J.F.; COELHO, M.R.; ALMEIDA, J.A. de; CUNHA, T.J.F.; OLIVEIRA, J.B. de. Sistema brasileiro de classificação de solos. 3.ed. Brasília: Embrapa, 2013. 353p.

WUTSCHER, H.K.; BOWMAN, K.D. Performance of 'Valencia' orange on 21 rootstocks in Central Florida. HortScience, v.34, p.622-624, 1999.

$\overline{\text { Received on April 14, } 2015 \text { and accepted on September 1, } 2017}$ 